\title{
PENGEMBANGAN KONSEPSI KURIKULUM DALAM PENDIDIKAN ISLAM
}

\author{
Yunus Mustaqim \\ SMK Al-Madina Demak, Jawa Tengah, Indonesia \\ cestercity@gmail.com
}

\begin{abstract}
Abstrak
Dinamika perkembangan kurikulum pendidikan Islam perlu mendapat perhatian bagi praktisi pendidikan agar penetapan kebijakannya sesuai dengan tujuan. Diketahui bahwa pendidikan Islam di Indonesia masih jauh dari harapan karena masih banyak output yang belum memiliki kompetensi atau kepribadian yang diharapkan. Penelitian ini menganalisis tentang alasan mengapa kurikulum harus dikembangkan, faktor-faktor yang mempengaruhi perkembangan kurikulum, dan cara mengembangkan konsepsi kurikulum pendidikan Islam. Dengan melakukan penelitian kepustakaan, diperoleh hasil bahwa (1) Kurikulum pendidikan Islam harus dikembangkan untuk mencapai keberhasilan peserta didik baik dalam ranah kognitif, afektif, dan psikomotorik; (2) faktor yang mempengaruhi perkembangan kurikulum adalah; tujuan, tuntutan masyarakat global, isi atau materi yang disesuaikan dengan perkembangan ilmu pengetahuan dan teknologi, serta kondisi psikologis peserta didik; (3) untuk mengembangkan konsepsi kurikulum Pendidikan Islam, perlu adanya pemahaman pada masing-masing konsepsi kurikulum yang sudah dirumuskan oleh para ahli pendidikan. Konsepsi kurikulum yang dimaksud adalah: kurikulum akademik, humanistik, teknologi, dan rekonstruksi sosial.
\end{abstract}

Kata kunci: pengembangan konsep, kurikulum pendidikan Islam 


\begin{abstract}
The dynamics of the development of Islamic education curriculum needs to get attention for education practotioners so that the determination of policies can be objective. The problem is many education outputs do not have the expected competence or personality. This study analyzed the reasons why the curriculum should be developed, factors that influence, and how to develop curriculum conception. By doing library research, the result showed that (1) the Islamic education curriculum should be developed to achieve the success of learners in cognitive, affective, and psychomotor; (2) factors affecting the development are purposes, demands of the global community, and contents or materials (3) to develop a conception of the curriculum of Islamic education, the need for understanding on their respective conceptions of the curriculum that has been formulated by education experts. The conceptions of the curriculum are: the academic curriculum, humanistic, technological, and social reconstruction.
\end{abstract}

Keywords: concept development, the curriculum of Islamic education

\title{
A. Pendahuluan
}

Dewasa ini, kurikulum sudah menjadi disiplin ilmu tersendiri dan telah berkembang cukup signifikan, baik secara teoritis maupun praktis. Dahulu, kurikulum dinamakan kurikulum tradisional yang lebih banyak memfokuskan mata pelajaran dengan metode klasik/ dominasi ceramah. Sesuai dengan tuntutan era global, sekarang kurikulum dinamakan kurikulum modern yang lebih banyak diorientasikan pada kecakapan hidup (life skill), pengembangan diri, pembangunan politik, hukum, ekonomi, industri, dan sosial-budaya untuk menciptakan peradaban dunia yang tertata rapi. Era global dengan berbagai permasalahannya, seperti; ekonomi, politik, hukum, sosial-budaya, yang kesemuanya membutuhkan ranah praktik dengan persyaratan teknologi informasi dan komunikasi.

Wujud perkembangan ini terkait dengan aspek immaterialpsikologis yang syarat membutuhkan perhatian, pemeliharaan, pengajaran, pendidikan dan bimbingan dalam rentang waktu yang relatif panjang. Demikian pula perkembangan kurikulum yang diterapkan di negeri ini pernah membutuhkan waktu 10 tahun pemberlakuannya. Namun demikian, kurun waktu yang relatif panjang tersebut nampaknya tidak seiring dengan perkembangan ilmu pengetahuan dan teknologi yang sangat cepat, boleh dibilang 
hanya hitungan harian, bulanan atau tahunan. Untuk mempermudah pemahaman tentang faktor-faktor perkembangan kurikulum, maka perlu upaya penguasaan landasan kurikulum yang mencakup empat hal. Pertama, filosofis, yaitu mencari tujuan pendidikan yang benar dalam kehidupan komunitas tertentu. Kedua, psikologis, yakni sesuai dengan perkembangan kejiwaan anak. Ketiga, sosiologis, yaitu sesuai dengansituasi/kebutuhan masyarakat. Dan organisatoris, yaitu relevan dengan bentuk bagaimana pelajaran itu disampaikan. Adapun faktor yang mempengaruhi perkembangan kurikulum pada umumnya adalah tujuan yang hendak dicapai melalui aneka ragam metode, tuntutan masyarakat global, isi atau materi yang disesuaikan dengan perkembangan ilmu pengetahuan dan teknologi, serta kondisi psikologis peserta didik. Dan khusus untuk faktor-faktor perkembangan kurikulum Pendidikan Agama Islam, perlu adanya tambahan, yaitu faktor sumber hukum Islam al-Qur'an dan al-Hadits yang multi interpretasi.

Disiplin ilmu kurikulum ini harus membuka diri terhadap kekuatan internal dan eksternal yang dapat memengaruhi proses perkembangan kurikulum dari yang konvensional menjadi inkonvensional, dari yang tradisional/klasik menjadi modern. Karena bagaimanapun itu, out put peserta didik nanti akan menjadi berkualitas atau tidak sangat dipengaruhi oleh kurikulum itu sendiri. Melihat pentingnya kurikulum dalam pendidikan ini, maka dalam waktu tertentu kurikulum selalu dievaluasi untuk disesuaikan dengan perkembangan teknologi dan informasi tersebut.

Dengan perkembangan media teknologi sekarang dan seterusnya, tidak dapat dipungkiri bahwa perkembangan tersebut akan memacu perkembangan pengetahuan dan metode belajar pun semakin bervariasi. Oleh karena itu, tidak mungkin dalam suatu institusi pendidikan tetap mempertahankan kurikulum tradisional. Hal ini dikhwatirkan akan mengakibatkan institusi tersebut tidak dapat bersaing dengan institusi lainnya yang memacu diri melengkapi sarana-prasarananya dengan media teknologi canggih.

Dalam UUSPN No. 20 Tahun 2003, dinyatakan bahwa kurikulum adalah seperangkat rencana dan pengaturan mengenai tujuan, isi, dan bahan pelajaran serta cara yang digunakan sebagai pedoman penyelenggaraan kegiatan pembelajaran untuk mencapai 
tujuan pendidikan tertentu (UUSPN, 2003: 6.) Engkoswara, guru besar Universitas Pendidikan Indonesia Bandung telah membuat 4 (empat) rumus pengertian kurikulum, lengkap dengan visualisasinya. Pertama, kurikulum adalah jarak yang harus ditempuh oleh pelari. Kedua, kurikulum adalah sejumlah mata pelajaran. Ketiga, kurikulum adalah sejumlah mata pelajaran dan kegiatan-kegiatan yang harus dilakukan oleh peserta didik. Keempat, kurikulum adalah sejumlah mata pelajaran dan kegiatan-kegiatan, serta segala sesuatu yang akan berpengaruh dalam upaya pencapaian tujuan pendidikan yang telah ditetapkan. Rumus ini memudahkan kita untuk memahami pengertian kurikulum.

Realita tersebut memang berposisi sebagai objek periferal dalam proses pengembangan kurikulum nasional. Posisi sebagai objek ini tidak menguntungkan karena ia seringkali diabaikan oleh para otoritas pengembang kurikulum. Sayangnya, kedudukannya yang menjadi objek berubah menjadi subjek dan penentu dalam implementasi kurikulum tetapi tetap tidak dijadikan landasan ketika guru mengembangkan kurikulum. Padahal keragamanitu berpengaruh langsung terhadap kemampuan guru dalam melaksanakan kurikulum, kemampuan sekolah dalam menyediakan pengalaman belajar, dan kemampuan siswa dalam proses belajar serta mengolah informasi menjadi sesuatu yang dapat diterjemahkan sebagai hasil belajar. Artinya, keragaman itu menjadi suatu variabel bebas yang memiliki kontribusi sangat signifikan terhadap keberhasilan kurikulum baik sebagai proses maupun sebagai hasil.

Posisi keragaman sebagai variabel bebas memang berada pada tataran sekolah dan masyarakat di mana suatu kurikulum dikembangkan dan diharapkan menjadi pengubah yang tangguh sesuai dengan kebutuhan masyarakat yang dapat diperkirakan (perceived needs of a society). Secara nyata pengaruh tersebut berada pada diri guru yang bertanggungjawab terhadap pengembangan kurikulum dan pada siswa yang menjalani kurikulum. Dengan kata lain, pengaruh tersebut berada pada tataran yang tidak boleh diabaikan sama sekali di mana studi kurikulum memperlihatkan kerentanan, dan kemungkinan besar kurikulum berubah atau bahkan berbeda sama sekali dengan apa yang telah direncanakan dan diputuskan. Oleh karena itu, keragaman sosial-budaya nasional harus 
menjadi faktor yang diperhitungkan dan dipertimbangkan dalam penentuan filsafat, teori, visi, pengembangan dokumen, sosialisasi kurikulum, dan pelaksanaan kurikulum.

Masyarakat sebagai sumber belajar harus dapat dimanfaatkan sebagai sumber konten kurikulum. Oleh karena itu, nilai, moral, kebiasaan, adat/tradisi, dan cultural tertentu harus dapat diakomodasi sebagai konten kurikulum. Konten kurikulum haruslah tidak bersifat formal semata, tetapi society and cultural-besed, dan open to problems yang hidup dalam masyarakat. Konten kurikulum haruslah menyebabkan siswa merasa bahwa sekolah bukanlah institusi yang tidak berkaitan dengan masyarakat, tetapi sekolah adalah suatu lembaga sosial yang hidup dan berkembang di masyarakat. Selanjutnya, konten kurikulum harus dapat menunjang tujuan kurikulum dalam mengembangkan kualitas kemanusiaan peserta didik.

Dari deskripsi di atas bahwa dinamika perkembangan kurikulum pendidikan Islam perlu mendapat perhatian bagi praktisi pendidikan yang berposisi menentukan kebijakan pendidikan nasional pada umumnya dan para teknisi pelaksana pendidikan Islam, guru/pendidik, pada khususnya. Hal ini mengingat bahwa pendidikan Islam di Indonesia masih jauh dari harapan dalam menjadikan out put-nya yang benar-benar memiliki kompetensi, khususnya kepribadian. Banyak fenomena yang terjadi bahwa siswa yang dikenal panggilannya "murid" di institusi Islam, seperti; murid MI, MTs, dan MA tidak jauh berbeda perilaku/kepribadiannya dengan siswa di SD, SMP, dan SMA. Dengan menggunakan penelitian kepustakaan atau library research, maka penulis merumuskan masalah sebagai berikut:

1. Mengapa kurikulum harus dikembangkan?

2. Faktor apa yang mempengaruhi perkembangan kurikulum?

3. Bagaimana mengembangkan konsepsi kurikulum pendidikan Islam?

Adapun manfaat yang ingin dicapai adalah bagi para praktisi pendidikan untukselalu mengkontrol dan mengevaluasi perkembangan kurikulum, baik yang berskala nasional (umum), maupun khusus, yaitu kurikulum pendidikan Islam. Disamping itu, bermanfaat bagi institusi dan guru untuk selalu melaksanakan kurikulum secara tepat dengan disertai evaluasi berdasarkan pengalamannya di lapangan 
Yunus Mustaqim

sehingga kurikulum nasional dan pendidikan Islam mencapai sasaran yang tepat guna bagi peserta didiknya.

\section{B. Pembahasan}

\section{Kurikulum Harus Dikembangkan}

Dinamika perkembangan kurikulum tidak pernah berhenti, dan pada umumnya merupakan salah satu upaya untuk meningkatkan kualitas pendidikan di negeri ini. Ia sebagai perangkat yang membantu praktisi pendidikan untuk memenuhi kebutuhan peserta didik yang nantinya diharapkan mampu sebagai agen perubahan kehidupan masyarakat yang lebih baik. Dinamika perkembangan kurikulum pendidikan Islam ini pada khususnya juga merupakan media bantu pendidik untuk melakukan tugas mengajarnya dalam memahamkan materi ajar peserta didik lebih cepat dan akurat.

Keanekaragaman sosial budaya nasional menjadi dasar dalam mengembangkan dinamika perkembangan kurikulum pendidikan Islam seperti tujuan, konten, proses, dan evaluasi. Pengembangan kurikulum di negara yang dikatakan cukup banyak penduduknya dan luas wilayahnya ini, bukanlah suatu pekerjaan yang mudah. Keragaman etnis, bahasa, agama, adat, sosial, budaya, aspirasi politik, dan kemampuan ekonomi memberikan tekanan yang sama, kalau tidak dapat dikatakan lebih kuat dibandingkan perbedaan filosofi, tujuan, visi, dan misi, serta teori yang dianut para pengambil keputusan mengenai kurikulum. Perbedaan filosofi, tujuan, visi, misi dan teori pengambil keputusan seringkali dapat diselesaikan melalui jenjang otoritas yang dimiliki seseorang walaupun dilakukan dalam suatu proses deliberasi yang paling demokratis sekalipun. Ketika perbedaan tersebut terselesaikan, maka proses pengembangan dokumen kurikulum dapat dilakukan dengan mudah. Tim yang direkrut adalah tim yang diketahui memiliki filosofi, visi, dan teori yang sejalan atau bahkan mereka yang tidak memiliki ketiga kualitas itu tetapi ahli dalam masalah konten yang akan dikembangkan sebagai konten kurikulum.

Pengertian kurikulum yang beraksentuasi pada seperangkat rencana dan pengaturan proses pembelajaran mempunyai beberapa unsure berikut. 
1. Tujuan; merupakan suatu yang diharapkan atau arah yang akan dicapai berdasarkan perencanaan terlebih dahulu. Dalam proses pembelajaran hendaknya mengacu pada tujuan nasional, tujuan institusional, tujuan kurikuler dan tujuan instruksional. Adapun tujuan yang dimaksud disini adalah tujuan instruksional, yaitu tujuan yang dicapai oleh peserta didik setelah mengikuti proses pembelajaran dan pengajaran pada bidang studi tertentu berdasarkan perencanaan yang sudah matang. Secara umum untuk tujuan pendidikan Islam adalah meningkatkan keimanan dan ketakwaan melalui penguasaan pengetahuan, pemahaman, penghayatan, pengamalan sehingga peserta didik menjadi insanul kamil.

2. Isi/materi; merupakan materi yang berkenaan dengan pengetahuan ilmiah dan pengalaman belajar peserta didik. Sudjana (1996: 30-31). memberikan kriteria tentang isi kurikulum yang baik sebagai berikut: 1) sesuai, tepat dan bermakna bagi tahap perkembangan anak; 2) mencerminkan kenyataan social; 3) mengandung aspek intelektual, moral, sosial secara seimbang; 4) mengandung pengetahuan ilmiah; 5) berdasarkan teori, prinsip, konsep yang jelas; dan 6) dapat menunjang tercapainya tujuan pendidikan.

3. Bahan pelajaran; yang dimaksud adalah mata pelajaran. Mata pelajaran tersebut sebagai bagian dari isi kurikulum yang menghasilkan berbagai aspek kehidupan masyarakat, seperti pengetahuan, kesenian, kebudayaan, sistem nilai dan keterampilan yang didasarkan pada norma-norma.

4. Cara yang digunakan; berarti metode pembelajaran hendaknya disesuaikan dengan tujuan, media, jenjang pendidikan, jenis mata pelajaran, situasi kelas berdasarkan kuantitas siswa, dan kondisi psikologis peserta didik. Berbicara tentang cara/metode pembelajaran sangat tergantung pada kualitas pendidik, artinya pendidik yang kaya penguasaannya pada metode dan variasi dalam mengaplikasikannya di kelas. Maka, semakin baik, karena bagaimanapun tidak ada suatu metode yang baik dan benar, melainkan yang ada adalah metode yang tepat dan tidak tepat, karena masing-masing metode mempunyai kelebihan dan kelemahan. 
5. Evaluasi; UUSPN No. 20 tahun 2003 juga disebutkan bahwa evaluasi hasil belajar peserta didik merupakan kegiatan yang dilakukan oleh pendidik untuk memantau proses, kemajuan, dan perbaikan hasil belajar peserta didik secara berkesinambungan.Amir Daien Indrakusuma memberikan definisi evaluasi atau tes adalah suatu alat atau prosedur yang sistematis dan obyektif untuk memperoleh datadata atau keterangan-keterangan yang diinginkan tentang seseorang dengan cara yang boleh dikatakan tepat dan cepat (Indrakusuma, 1975: 27). Pengertian lain, tes adalah "Test is comprehensive assessment of an individual or to an entire program evaluation effort" (Anderson, dkk, 1976: 425). Maksudnya "Tes adalah peneilaian secara komprehensif (menyeluruh) pada individu atau pada keseluruhan usaha evaluasi program".

Dengan demikian, komponen evaluasi pada dasarnya memiliki ciri khas tersendiri bila dibandingkan dengan komponen kurikulum lainnya. Hal ini mengingat bahwa evaluasi sudah memiliki persyaratan ilmiah tersendiri untuk menjadi suatu ilmu evaluasi yang mandiri.

Pada prinsipnya membentuk kurikulum yang ideal itu sama dalam hal pemenuhan; rumusan tujuan, isi/materi pokok, pengorganisasian bahan pelajaran, kesiapan media dan lingkungan, metode yang digunakan, serta evaluasi yang diterapkan. Mereka merupakan satu kesatuan yang saling menunjang keberhasilan peserta didik baik berupa pengontrolan penalaran (kognitif), perilaku (afektif), pengalaman dan keterampilan (psikomotorik). Dan mengecilkan peran salah satunya akan berimplikasi pada sulitnya pencapaian hasil pembelajaran yang diharapkan.

Keberadaan kurikulum pendidikan Islam harus selalu dikembangkan sehingga akan menjadikan institusi pendidikan Islam senantiasa diharapakn oleh semua pihak. Fenomena itu dapat ditilik adanya kurikulum pendidikan Islam yang mendasar dan yang menyentuh kebutuhan dasar, yaitu melihat kebutuhan vital masyarakat. Kurikulum pendidikan Islam menghindari adanya kurikulum yang tumpang tindih. Tumpang tindihnya kurikulum dari satu materi pelajaran ke materi pelajaran lainnya yang diberlakukan secara transparan atau umum akan menjadikan proses pembelajaran 
menjadi jenuh. Padahal sumber kurikulum pendidikan Islam sudah jelas sistematisnya, yaitu al-Qur'an dan al-Sunnah.

Dengan demikian, diharuskannya pengembangan kurikulum pendidikan Islam yang baik sebagai parameter kualitas dan tidaknya suatu pendidikan harus memiliki visi, misi, konsep dan tujuan yang jelas dan seimbang antara muatan teoritis dan praktis. Muatan teoritis berarti memberi landasan dari berbagai teori yang ada, sehingga melahirkan suatu analisis dan hipotasis yang objektif dan ilmiah. Sedangkan muatan praktis adalah mem-follow up dalam format realitas kerja fisik yang profesional.

Kurikulum pendidikan Islam harus dikembangkan dalam mencapai keberhasilan peserta didik tidak dalam ranah kognitif semata, karena hal ini akan melahirkan demoralisasi peserta didik, yakni kurangnya peserta didik dalam kompetensi kepribadian dan minimnya keterampilan yang membawa peserta didik selalu dalam ketergantungan hidupnya. Kognitif yang berarti kemampuan rasional, afektif kemampuan dalam merealisasi tingkah laku yang positif dan berperasaan, dan psikomotorik sebagai refleksi dan keterampilan fisik harus diseimbangkan sedemikian rupa, sehingga cipta, rasa, dan karsa benar-benar dapat dinikmati oleh peserta didik pada khususnya dan masyarakat umumnya.

Adanya upaya baru berupa sistem pembelajaran link and match (keterkaitan dan kesepadanan) yang dikembangkan sekarang dan menjadi alternatif pertama belumlah menjadi suatu sistem dan metode yang menjanjikan eksistensinya. Link and match sebagaimana digambarkan Prof. Malik Fajar dalam bukunya Visi Pembaruan Pendidikan Islam hanya merupakan sebagian aspek yang peranannya menghubungkan program studi antara ilmu-ilmu lunak dengan ilmu-ilmu keras (soft sciences dengan hard sciences) idealnya 1:3 atau 1:4 dengan melihat realitas perkembangan ilmu pengetahuan dan teknologi tidaklah harus dijustifikasi sedemikian rupa dan diikuti sepenuhnya. Melainkan harus dipandang pula kecenderungan kultural masyarakat kita yang berbasis religius. Di mana kegagalan pendidikan yang dialami bangsa Indonesia sekarang ini adalah kurangnya muatan kurikulum yang menyentuh pada aspek humanistik yang berakar dari nilai-nilai normatif keagamaan. 
Yunus Mustaqim

Oleh karena itu, kurikulum pendidikan Islam harus dievaluasi dan dikembangkan seiring dengan perkembangan budaya dan peradaban manusia. Perkembangan ini senantiasa menggunakan pendekatan secara holistik, yakni menggali semua potensi peserta didik yang berupa bakat, minat, mental, emosi, perilaku, keterampilan personal dan sosial secara seimbang.

Bakat merupakan kemampuan alamiah peserta didik yang dibawa sejak lahir. Minat adalah keinginan peserta didik untuk mengetahui atau melakukan sesuatu. Mental berarti kondisi psikis peserta didik dalam merespon suatu obyek apakah stabil atau instabiltas. Emosi mencerminkan reaksi peserta didik terhadap gejala atau peristiwa yang berada baik dalam dirinya ataupun di luar dirinya. Perilaku mencerminkan tingkah laku yang sudah menjadi kebiasaan baik disadari maupun tidak. Keterampilan sebagai cerminan kreativitas peserta didik dalam menyelesaikan masalah kehidupannya secara cepat, tepat dan berhasil guna berdasar al-Qur'an dan al-Sunnah.

\section{Faktor Pengaruh Perkembangan Kurikulum Pendidikan Islam}

Kurikulum sebagai buku pedoman (guidance book) primer proses belajar mengajar baik dalam ruang lingkup nasional sekolah formal khususnya, nonformal, dan informal umumnya berada pada posisi sentral dalam mengembangkan kemampuan peserta didik yang berupa aspek kognitif, afektif dan pikomotorik peserta didik secara simultan. Aspek-aspek tersebut merupakan kesatuan yang utuh dan seimbang.

Banyak faktor yang mempengaruhi perkembangan kurikulum pada umumnya adalah tujuan yang hendak dicapai, tuntutan masyarakat global, isi atau materi yang disesuaikan dengan perkembangan ilmu pengetahuan dan teknologi, serta kondisi psikologis peserta didik. Di samping itu, faktor yang terpenting lagi mempengaruhi perkembangan kurikulum kaitannya dengan Pendidikan Islam adalah faktor sumber hukum Islam berupa alQuran-Hadits.

Parameter perumusan tujuan dalam pengembangan kurikulum diantaranya tujuan harus menggambarkan jenis tingkah laku, tujuan yang kompleks perlu dijelaskan sehingga tidak mengaburkan perilaku, tujuan harus mengarah pada perilaku dari pengalaman belajar, tujuan 
harus menggambarkan bentuk perilaku yang dapat dikembangkan lebih lanjut dalam konteks yang berbeda-beda, tujuan harus bersifat realistis, tujuan harus luas yang dapat membentuk perilaku siswa.

Kecenderungan masyarakat global adalah pragmatis, dan interaksi mereka tanpa terbatasi oleh tempat dan waktu. Hal ini menuntut kurikulum harus dinamis pula. isi/materi kurikulum yang ideal hendaknya; sesuai dengan tahap perkembangan peserta didik, mencerminkan kenyataan sosial, keseimbangan aspek intelektual, moral, sosial, berdasarkan teori, prinsip, konsep yang jelas dan harus dapat menunjang tercapainya tujuan pendidikan

Faktor psikologis peserta didik dalam mempengaruhi rancang bangun kurikulum menjadi persoalan yang amat penting, karena belajar merupakan aktivitas yang amat kompleks. Ada belajar yang berupa fakta kongkrit, ada belajar dalam memecahkan dan menganalisis masalah, dan ada belajar tentang mengamati nilai-nilai sosial yang abstrak.

Al-Qur'an dan al-Hadits mempunyai pengaruh besar dalam pengembangan kurikulum, karena nilai-nilai yang terkandung di dalamnya syarat dengan banyaknya kemunculan ilmu pengetahuan dan teknologi yang serba baru dan modern. Al-Quran telah memberikan kepuasan penalaran yang sesuai dengan kesederhanaan dan fitrah manusia tanpa unsur paksaan dan di sisi lain disertai dengan pengutamaan afeksi dan emosi manusia.

Secara konkret, dapat dicermati dari paparan di atas bahwa faktor yang mempengaruhi dinamika perkembangan kurikulum pendidikan Islam adalah sebagai berikut:

\section{a. Faktor Tujuan}

Tujuan menjadi modal dasar setiap langkah kegiatan manusia, terlebih dalam pendidikan yang melibatkan pendidik dan peserta didik. Mereka sama-sama hidup yang mempunyai tujuan sama, yaitu menjadi manusia yang berguna bagi dirinya sendiri, agama, nusa dan bangsa. Tujuan menjadi faktor penyebab pengembangan kurikulum menurut Hilda Taba yang dikutip oleh Ali (1992: 87-89) bahwa tolok ukur rumusan tujuan sebagai berikut:

1. Pernyataan tujuan harus menggambarkan jenis tingkah laku yang diharapkan serta isi atau konteks penerapannya. 
Yunus Mustaqim

2. Rumusan tujuan yang kompleks perlu dijabarkan sehingga tidak mengaburkan jenis perilaku yang diharapkan.

3. Rumusan tujuan harus jelas menggambarkan bentuk perilaku dari berbagai pengalaman belajar yang hendak dicapai.

4. Rumusan tujuan harus menggambarkan bentuk-bentuk perilaku yang dapat dikembangkan lebih lanjut dalam konteks yang berbeda-beda.

5. Tujuan harus bersifat realistis sehingga dapat diwujudkan dalam kurikulum maupun dalam bentuk pengalaman belajar di kelas.

6. Ruang lingkup tujuan harus luas sehingga dapat menembus berbagai bentuk hasil siswa yang menjadi tanggungjawab sekolah.

Adapun langkah-langkah teknis perumusan tujuan kurikulum adalah: 1. Menganalisis kebutuhan, 2. Menganalisis sumber tujuan, 3. Mengembangkan tujuan sekolah, 4. Mengembangkan jenis pengalaman belajar dan organisasinya, 5. Menjabarkan tujuan sekolah sesuai dengan lingkup dan urutan pengalaman belajar yang ditentukan, 6. Mengembangkan tujuan bidang studi, 7. Mengembangkan bahan pelajaran, 8. Menjabarkan tujuan bidang studi, 9. Mengembangkan tujuan pengajaran umum, 10. Menjabarkan tujuan pengajaran umum ke dalam tujuan pengajaran khusus (Ali, 1992: 89-90).

\section{b. Faktor Tuntutan Masyarakat}

Dampak globalisasi dan industrialisasi pada peradaban dunia merujuk kepada sesuatu pengaruh yang mendunia, paling tidak ditandai oleh penyebaran arus informasi yang melanda dunia tanpa terbatasi wilayah atau penyebaran jaringan produksi, produk industri dari satu negara ke negara lain (Feisal, 1995: 129). Berhubungan dengan dunia pendidikan, berbagai perkembangan di bidang ilmu pengetahuan dan teknologi, seperti kemajuan teknologi komunikasi, informasi, dan unsur budaya lainnya akan mudah diketahui oleh masyarakat. Kecenderungan seperti ini harus diantisipasi oleh dunia pendidikan jika kita ingin menempatkan pendidikan sebagai agen pembangunan dan perkembangan yang tidak ketinggalan zaman (Feisal, 1995: 131).

Melihat kecenderungan masyarakat global tersebut pengem- 
bangan kurikulum "tanpa terbatasi oleh waktu minimal atau maksimal” menjadi suatu keniscayaan sesuai dengan karakteritik kurikulum itu sendiri, yakni dinamis. Karakter kurikulum yang dinamis sangat tergantung kreatifitas pelaku pendidikan, yaitu; kepala sekolah, pendidik, dan pemerintah yang berkompeten. Dengan demikian, kecenderungan masyarakat global yang pragmatis ini sangat memberi pengaruh pada perubahan dan perkembangan kurikulum yang realistis sesuai dengan kebutuhan masyarakat pada umumnya.

\section{c. Faktor Isi/Materi}

Isi/materi merupakan salah satu komponen pendidikan. Artinya tanpa materi proses pembelajarn tidak mungkin terjadi. Dalam hal ini materi harus disesuaikan dengan kebutuhan masyarakat sebagai pengguna jasa dari kalangan akademisi yang profesional.

Faktor isi/materi tersebut sangat mempengaruhi perkembangan kurikulum dengan alasan bahwa masih banyak problematika yang harus dipecahkan melalui validitas kurikulum yang diajarkan sekolah kepada peserta didiknya. Oleh karena itu, isi/materi kurikulum hendaknya disesuaikan dengan hasil-hasil penelitian atau penemuan ilmu pengetahuan dan teknologi yang syarat dengan kebaruannya.

\section{d. Faktor Psikologis Peserta Didik}

Disamping psikologis sebagai landasan rancang bangun kurikulum, kondisi psikologis anak juga dapat sebagai faktor yang mempengaruhi pengembangan kurikulum. Faktor psikologis tersebut berbicara tentang kondisi kejiwaan seseorang dalam merespon suatu obyek. Untuk merancang dan membuat kurikulum perlu memperhatikan murid dalam belajar, karena belajar ternyata suatu aktivitas yang amat kompleks. Ada belajar yang berupa fakta kongkrit, ada belajar dalam memecahkan dan menganalisis masalah, ada belajar tentang mengamati nilai-nilai sosial yang abstrak.

Dalam kajian psikologi terdapat teori ilmu jiwa daya atau mental disiplin dan ilmu jiwa asosiasi. Teori ilmu jiwa daya menganggap bahwa otak atau mental manusia terdiri dari sejumlah faculties atau daya-daya. Tiap daya mempunyai fungsi tertentu, maka ada daya ingat, daya pikir, daya tanggap, daya fantasi dan lainlainnya. Sedangkan ilmu jiwa asosiasi beranggapan bahwa untuk 
memperoleh pengetahuan metode yang paling tepat adalah $S-R$, yaitu menghubungkan stimulan (rangsangan) dan respon (tanggapan). Disamping itu dalam teori ilmu jiwa terdapat teori gestal, yaitu belajar yang mengutamakan keseluruhan lebih dari jumlah bagian-bagiannya. Teori ini beranggapan bahwa manusia cenderung melihat suatu pola, organisasi, integrasi atau konfigurasi dalam apa yang dilihatnya (Nasution, 1995: 68)

Dengan demikian faktor kondisi psikologis peserta didik mempunyai pengaruh terhadap pengembangan kurikulum. Sebagai contoh, mayoritas peserta didik dalam suatu negara yang dilanda kerusuhan, perang saudara, atau dalam kehidupan keluarganya, orang tua/ayah-ibu, tidak harmonis akan menjadikan peserta didik tersebut terganggu konsentrasinya dalam belajar yang imbasnya adalah proses pembelajaran tidak maksimal. Hal ini lain dengan peserta didik yang berada dalam negara yang aman, tenteram, makmur dan dalam kehidupan keluarganya harmonis, maka akan menjadikan peserta didik semangat dalam belajar.

\section{e. Faktor Sumber Hukum Islam}

Al-Qur'an dan al-Hadits dijadikan sumber pembelajaran dalam Pendidikan Agama Islam. Pengaruhnya terhadap pengembangan kurikulum tidak bisa dihindari dalam kondisi apapun, karena nilai-nilai yang terkandung di dalamnya syarat dengan banyaknya kemunculan ilmu pengetahuan dan teknologi yang serba baru dan modern.

Abdurrahman an-Nahlawi (1983: 29-30) menggambarkan bahwa al-Qur'an telah memberikan kepuasan penalaran yang sesuai dengan kesederhanaan dan fitrah manusia tanpa unsur paksaan dan di sisi lain disertai dengan pengutamaan afeksi dan emosi manusiawi. Dengan demikian al-Qur'an mengetuk akal dan hati sekaligus. AlQur'an ini mengawali konsep pendidikannya dari hal yang sifatnya kongkrit, seperti hujan, angin, tumbuh-tumbuhan, guntur, atau kilat menuju hal yang abstrak, seperti keberadaan (kebijaksanaan), kebesaran, kekuasaan dan berbagai sifat kesempurnaan Allah SWT. Metode yang ditawarkan pun dalam pendidikan mencakup metode bertanya baik untuk tujuan mengkritik maupun mengingatkan, metode yang menggembirakan dengan penekanan pada kemampuan afeksi manusia. 


\section{Mengembangkan Konsepsi Kurikulum Pendidikan Islam}

Kurikulum mempunyai komponen dan struktur. Komponen adalah bagian yang mempunyai fungsi masing-masing dari keseluruhan sesuatu yang ada. Komponen kurikulum mencakup; isi, bahan pelajaran, cara/metode dan evaluasi. Sedangkan struktur kurikulum adalah untuk membangun atau menyusun perencanaan kegiatan sehingga sesuai dengan tujuan yang diharapkan. Struktur yang dimaksud dalam pengembangan kurikulum pendidikan Islam hendaknya didasarkan pada identifikasi kompetensi, pengembangan struktur kurikulum dan pendeskripsian bidang studi. Kurikulum pendidikan Islam sangat interest pada identifikasi kompetensi, yakni meningkatkan kemampuan untuk menjadikan peserta didik terampil dalam segala bidang. Pengembangan struktur kurikulum menjadi suatu keniscayaan karena bidang-bidang studi yang tercakup mencerminkan tingkat kemampuan peserta didik. Dan pendeskripsian mata pelajaran/bidang studi akan mempermudah tujuan kurikuler tercapai karena sudah memfokuskan pada karakteristik bidang studi masing-masing.

Namun dalam realitasnya format kurikulum antara satu dengan lainnya terkadang banyak ditemui perbedaannya. Hal ini dikarenakan adanya perspektif yang berbeda antara ideologi pembuat kurikulum satu dengan lainnya dalam menentukan tujuan, orientasi, metode dan konsep pendidikan yang berlainan pula. Dalam kurikulum pendidikan Islam, tentunya didasarkan pada landasan filosofis, al-Qur'an dan al-Sunnah, yang mengedepankan amaliah, perilaku/kepribadian dengan didukung keterampilan serta penalaran intelektual. Karena bagaimanapun tujuan utama Nabi Muhammad saw. diutus oleh Allah Swt adalah untuk menyempurnakan atau memperbaiki akhlak manusia.

An-Nahlawi (1996: 196) mendeskripsikan karakter kurikulum Islam sebagai berikut: 1). Selaras dengan fitrah manusia. 2). Fundamental, memurnikan ketaatan pada Allah semata. 3). Relevan dengan tingkat pendidikan, jenis kelamain dan tugas kemasyarakatan. 4). Sesuai dengan tujuan, kebutuhan, realitas masyarakat. 5). Terbebas dari kontradiksi negatif, dan selaras dengan integritas psikologis. 6). Selaras dengan tujuan negara. 7). Penggunaan metode yang elastis/ 
fleksibel. 8). Penekanan pendidikan yang behavioristik. 9). Sesuai dengan tingkat usia peserta didik. 10). Sesuai dengan aktivitas islami secara langsung jihad, dakwah islamiyah.

Dengan demikian, kurikulum pendidikan Islam hendaknya benar-benar memperhatikan tingkat pendidikan yang dikelola baik pemerintah ataupun non-pemerintah. Tingkatan tersebut merupakan keniscayaan dengan melihat bahwa peserta didik yang sama dan berbeda dalam tingkat intelektualnya dalam satu kelas sangat mempengaruhi untuk siap atau tidaknya peserta didik tersebut menerima mata pelajaran.

Demikian pula kurikulum pendidikan Islam yang ideal hendaknya memperhatikan jenis kelamin peserta didik antara pria dan wanita dalam bentuk mata pelajaran tertentu. Seperti mata pelajaran yang terkait dengan kemampuan fisik perlu didominasikan pada peserta didik putra. Dan kurikulum Islam juga harus didesain sesuai dengan kebutuhan dan tugas kemasyarakatan. Karena bagaimanapun peserta didik adalah bagian dari komunitas masyarakat yang dapat mewarnai baik tidaknya kehidupan masyarakat itu sendiri. Kongkritnya kurikulum pendidikan Islam harus mengikuti perkembangan era global, informasi dan teknologi, namun harus pula mengacu pada sumber utama ilmu pengetahuan, yaitu al-Qur'an dan al-Sunnah.

Dalam RUU SPN No. 2 tahun 1989 telah memberikan warna baru untuk lembaga pendidikan Islam dimana dengan diberlakukannya UUSPN No 2 tahun 1989 madrasah-madrash mendapat perlakuan yang sama dengan sekolah umum lainnya.Karena dalam UUSPN tersebut madrasah dianggap sebagai sekolah umum yang berciri khas Islam dan kurikulum madrasah sama persis dengan sekolah umum plus pelajaran agama Islam sebanyak tujuh mata pelajaran. Secara operasional, integrasi madrasah ke dalam sistem pendidikan nasional ini dikuatkan dengan PP No. 28 tahun 1990 dan SK MenDepartemen Pendidikan Nasional No. 0487/U/ 1992 dan No. 054/U/ 1993 yang antara lain menetapkan bahwa MI/MTs wajib memberikan bahan kajian sekurang kurangnya sama dengan "SD/ SMP”. Surat-surat Keputusan ini ditindak lanjuti dengan SK Menteri Agama No. 368 dan 369 tahun 1993 tentang penyelenggaraan MI dan 
MTs. Sementara tentang Madrasah Aliyah (MA) diperkuat dengan PP Nomor 29 tahun 1990, SK MenDepartemen Pendidikan Nasional Nomor 0489/U/ 1992 (MA sebagai SMA berciri khas agama Islam) dan SK Menag Nomor 370 tahun 1993. Pengakuan ini mengakibatkan tidak ada perbedaan lagi antara MI/MTs/MA dan SD/SMP/SMA selain ciri khas agama Islamnya.

Terlebih mengacu pada UUSPN No. 20 Tahun 2003 bahwa pendidikan agama Islam mempunyai peluang mengembangkan kurikulumnya sendiri dan cukup diuntungkan oleh pemerintah. Hal ini dapat dilihat dari pasal demi pasal, seperti:

1. Tujuan Pendidikan Nasional sangat memberikan peluang untuk merealisasikan nilai-nilai al-Qur'an yang menjadi tujuan pendidikan Islam yaitu terbentuknya manusia yang beriman dan bertaqwa (Pasal 3).

2. Anak-anak Muslim yang sekolah di lembaga pendidikan Non Islam akan terhindar dari pemurtadan, karena anakanak tersebut akan mempelajari mata pelajaran agama sesuai dengan yang dianut oleh siswa tersebut dan diajarkan oleh guru yang seagama dengan dia (Pasal 12 ayat 1a)

3. Madrasah-madrasah dari semua jenjang terintegrasi dalam sistem pendidikan nasional secara penuh (Pasal 17 dan 18)

4. Pendidikan keagaamaan seperti Madrasah Diniyah dan pesantren mendapat perhatian khusus pemerintah, karena pendidikan keagamaan tidak hanya diselenggarakan oleh kelompok masyarakat tetapi juga diselenggarakan oleh pemerintah (Pasal 30).

5. Pendidikan Agama diajarkan mulai dari jenjang pendidikan dasar sampai dengan pendidikan tinggi (Pasal 37) (Harsono, 2014).

Adanya perubahan UUSPN No.2 tahun 1989 menjadai UU SISDIKNAS No. 20 tahun 2003 dimaksudkan agar sistem pendidikan nasional bisa menjadi jauh lebih baik dibanding dengan sistem pendidikan sebelumnya. Hal ini seperti yang dikemukan oleh seorang pengamat hukum dan pendidikan, Frans Hendrawinata, beliau mengatakan bahwa dengan adanya undang-undang sistem pendidikan nasional yang baru, maka diharapkan undang-undang tersebut dapat menjadi pedoman bagi kita untuk memiliki suatu 
sistem pendidikan nasional yang mantap, yang dapat menjamin terpenuhinya kebutuhan masyarakat akan sumber daya manusia yang berkualitas. Apalagi mengingat semakin dekatnya era keterbukaan pasar. Hal tersebut menjadi kekhawatiran bagi kita semua mengingat kualitas sumber daya manusia di Indonesia berada di bawah negaranegara lain termasuk negara-negara tetangga di Asean. Oleh sebab itulah diperlukan suatu platform berupa sistem pendidikan nasional yang dapat menciptakan sumber daya manusia yang mampu bersaing dengan dunia internasional khususnya dalam era keterbukaan pasar saat ini (Harsono, 2014).

Konsep merupakan ide atau gagasan seseorang dan konsepsi berarti gagasan atau cita-cita yang masih dalam pikiran. Ahmad Tafsir memberi makna konsep adalah definisi. Definisi ialah pengertian atau penyebutan semua ciri esensi suatu objek dengan membuang semua ciri aksidensinya. Ciri esensi adalah ciri yang menyebabkan objek sebagai objek itu sendiri (ciri pokok), sedangkan ciri aksidensi ialah ciri yang tidak pokok, maksudnya ciri tersebut boleh ada boleh tidak, atau tidak mempengaruhi ada tidaknya objek itu sendiri (Tafsir, 1997: 110).

Untuk menentukan arah pengajaran dan pendidikan dalam rangka mencapai tujuan yang optimal perlu adanya pemahaman pada masing-masing konsepsi kurikulum yang sudah dirumuskan oleh para ahli pendidikan. Konsepsi kurikulum yang dimaksud adalah: kurikulum akademik, humanistik, teknologi, dan rekonstruksi sosial. Untuk konsepsi kurikulum pendidikan Islam dengan ciri-ciri: sistem pengajaran selaras dengan fitrah manusia, lebih mengutamakan kepentingan umum daripada kepentinga pribadi, lebih mengutamakan 'amaliah (praktek) daripada nadhariah (teori).

\section{a. Kurikulum Akademik}

Akademik merupakan kegiatan yang bercirikan pengetahuan ilmiah melalui jalur pendidikan formal maupun nonformal. Sebagai insan akademisi tentunya dituntut untuk berfikir secara logis, empiris, kritis, cerdas, mandiri dan proaktif yang dapat dipertangungjawabkan di hadapan publik.

Adanya konsepsi kurikulum akademik ini, didasarkan pada kesadaran tentang pentingnya kemajuan ilmu pengetahuan 
dan teknologi.yang menuntut peserta didik memiliki kemampuan intelektual (kognitif) tinggi (cerdas). Memang manusia (peserta didik) mempunyai kelebihan yang tidak ada bandingannya dengan makhluk lainnya. Kelebihan ini adalah manusia diberi akal (intelektual) yang disuruh untuk mengembangkannya melalui pendidikan.

Akal dapat dididik dan dikembangkan semaksimal mungkin, terlebih lagi jika sesuai dengan bakat dan minatnya. Allah Swt telah menciptakan manusia dengan bekal akal sehingga dapat menguasai dan menundukkan alam semesta untuk kemaslahatan umat manusia, bukan untuk mafsadatul umat. Itulah dasar pendidikan Rabbani yang melahirkan harga diri manusia itu sendiri. Jadi akal membutuhkan proses pendidikan yang tidak kenal batas tempat dan waktu.

Ayat al-Qur'an yang pertama kali diturunkan adalah surat al'Alaq, dimulai dengan kata iqra (bacalah), kemudian Allah mengikut sertakan kata 'allama (mengajarkan).Ini menunjukkan terdapat kaitan yang sangat erat antara kegiatan membaca dengan pengajaran. Membaca dan pengajaran ini dikemas dalam proses pendidikan sehingga menjadi konsepsi akademik pendidikan Islam berdasarkan al-Qur'an. Membaca yang baik dan benar, dan bisa cepat dengan disertai pemahaman makna yang terkandung dalam bacaan tersebut secara komprehensif, manakala kegiatan membaca ini dilaksanakan dengan pengajaran yang terencana dan sistematis, yaitu adanya konsepsi akademik kurikulum pendidkian Islam yang bersumber alQur'an dan al-Hadits.

Al-Qur'an mendasari kegiatan pendidikan peserta didik sebagai manusia melalui metode penalaran intelektual dan pemahaman, penghayatan hati yang sarat dengan membaca, mengetahui, memahami, menghayati, meneliti, dan observasi ilmiah terhadap berbagai ilmu pengetahuan yang melingkupi peserta didik itu sendiri. Jadi, betapa pentingnya konsepsi kurikulum pendidikan Islam yang berbicara tentang profesi akademik, pengembangan intelektual.

\section{b. Kurikulum Humanistik}

Kurikulum ini menekankan pada pengembangan potensi peserta didik secara individual. Oleh karena itu, peserta didik diberi kesempatan untuk belajar sesuai dengan minat, bakat dan 
kebutuhannya sendiri. Dan dalam implementasi kurikulum ini, peserta didik dan pendidik terlibat langsung dalam menentukan rencana pembelajaran. Disamping mereka menjadi subyek pendidikan, juga sebagai obyek pendidikan. Dalam kata lain, konsepsi kurikulum humanistik proses pembelajaran berpusat pada anak (child centered curriculum) (Ali, 1992: 11). Konsepsi kurikulum humanistik mempunyai ciri-ciri: tujuan, metode, organisasi, dan evaluasi yang lebih mengutamakan proses daripada hasil, penilaian secara subyektif dilakukan oleh guru dan siswa itu sendiri (McNeil, 1988: 20-23).

Dalam konsep pendidikan Islam peserta didik sebagai makhluk memiliki banyak keinginan, kebutuhan, kepentingan dan permasalahan yang sangat kompleks. Walaupun peserta didik dengan akalnya dapat didik, akan tetapi kegiatan mendidik pada mereka ini tidak semudah yang dibayangkan oleh kebanyakan orang. Dalam kata lain, peserta didik berinteraksi dengan manusia lain, walaupun sudah saling kenal dan sudah jelas posisinya, yang satu sebagai pendidik dan lainnya terdidik, namun dalam realitasnya proses pendidikan tetap masih terdapat hambatan yang cukup signifikan. Hal ini berbeda, jika dibandingkan peserta didik berinteraksi dengan selain sesamanya, seperti; binatang atau makhluk lainnya, tentunya manusia akan mudah menguasai dan mengendalikannya. Oleh karena itu, konsepsi kurikulum humanistik dalam pendidikan Islam ini pendidik harus memberi kebebasan individu peserta didiknya untuk mengembangkan potensinya masing-masing yang tentunya tidak lepas dari bimbingannya yang didasarkan al-Quran dan al-Sunnah.

\section{c. Kurikulum Teknologi}

Konsepsi kurikulum teknologi ini memandang bahwa kurikulum merupakan suatu sistem. Sebagai sistem tentunya mempunyai sejumlah komponen yang saling tergantung dan keterkaitan sesuai dengan fungsinya masing-masing untuk mencapai tujuan. Oleh karenanya, rancang bangun dalam konsepsi kurikulum ini adalah dimulai dari perumusan tujuan yang akan dicapai, kemudian disediakan alat/media untuk mengukur keberhasilan, kemudian dilanjutkan pemenuhan bahan pelajaran, setelah itu penggunaan metode yang dianggap tepat dalam mencapai tujuan.

Konsepsi kurikulum ini lebih menekankan pada perancangan 
sistem belajar-mengajar berdasarkan pendekatan sistem. Penerapannya dalam praktek pendidikan tercermin dari penerapan sistem pengajaran individual. Di dalam pengajaran individual, setiap peserta didik dapat memilih bahan pelajarannya sendiri dan yang dapat dipelajari sendiri. Dengan demikian, setiap peserta didik dapat belajar sesuai dengan potensinya masing-masing, sehingga peserta didik yang berpotensi tinggi dapat belajar dan menguasai pelajaran lebih cepat dari peserta didikyang berpotensi lebih rendah (Ali, 1992: 13).

\section{d. Kurikulum Rekonstruksi Sosial}

Konsepsi kurikulum ini beraksentuasi pada pentingnya kurikulum sebagai alat untuk melakukan rekonstruksi atau penyusunan kembali corak kehidupan dan kebudayaan masyarakat. Penyusunan atau tatanan ini meliputi aspek kehiduapan; sosial, politik, ekonomi, mental, spiritual. Konsep ini peserta didik diajak untuk mengenali berbagai permasalahan yang muncul di masyarakat sesuai dengan tingkat berpikirnya, kemudian berusaha mencari alternatif pemecahannya. Adapun ciri-ciri konsepsi kurikulum ini adalah: 1). Untuk kepentingan penyusunan kurikulum perlu dilakukan analisis kebutuhan. 2). Berdasarkan kebutuhan-kebutuhan yang dapat dikenali dilakukan penentuan prioritas. 3). Proses pendidikan di sekolah menekankan pada kegiatan pemecahan masalah. 4). Masyarakat dijadikan sebagai sumber belajar (Ali, 1992: 12).

Dari empat macam konsepsi kurikulum secara umum tersebut ketika dikaitkan dengan pengembangan kurikulum pendidikan Islam dalam prinsipnya yaitu 1) menyeluruh/kaffah, 2) keseimbangan, 3) kesesuaian, 5) dinamis, 6) keterbukaan, 7) pemeliharaan, 8) toleransi.

Dari delapan prinsip tersebut, Arifin menyatakan bahwa prinsip yang harus diperhatikan saat menyusun kurikulum pndidikan Islam adalah sebagai berikut: 1) Kurikulum pendidikan yang sejalan dengan identitas Islami adalah kurikulum yang mengadung materi (bahan) ilmu pengetahuan yang mampu berfungsi sebagai alat untuk tujuan hidup Islami. 2) Untuk berfungsi sebagai alat yang efektif mencapai tujuan tersebut, kurikulum harus mengandung tata nilai Islami yang intrinsik dan ekstrinsik mampu merealisasikan tujuan 
pendidikan Islam. 3) Kurikulum yang bercirikan Islam itu diproses melalui metode yang sesuai dengan nilai yang terkandung di dalam tujuan pendidikan Islam. 4) Antara kurikulum, metode dan tujuan pendidikan Islam harus saling berkaitan produk yang bercita-cita menurut ajaran Islam (Ihsan dan Ihsan 2007: 135-136).

\section{Simpulan}

Berdasarkan analisis di poin sebelumnya, dapat disimpulkan sebagai berikut:

1. Kurikulum pendidikan Islam harus dikembangkan untuk mencapai keberhasilan peserta didik tidak dalam ranah kognitif semata, karena hal ini akan melahirkan demoralisasi peserta didik, yakni kurangnya peserta didik dalam kompetensi kepribadian dan minimnya keterampilan yang membawa peserta didik selalu dalam ketergantungan hidupnya. Kognitif yang berarti kemampuan rasional, afektif kemampuan dalam merealisasi tingkah laku yang positif dan berperasaan, dan psikomotorik sebagai refleksi dan keterampilan fisik harus diseimbangkan sedemikian rupa, sehingga cipta, rasa, dan karsa benar-benar dapat dimiliki peserta didik pada khususnya dan masyarakat umumnya.

2. Faktor yang mempengaruhi perkembangan kurikulum pada umumnya adalah: tujuan yang hendak dicapai, tuntutan masyarakat global, isi atau materi yang disesuaikan dengan perkembangan ilmu pengetahuan dan teknologi, serta kondisi psikologis peserta didik. Disamping itu, faktor yang terpenting lagi mempengaruhi perkembangan kurikulum kaitannya dengan Pendidikan Islam adalah faktor sumber hukum Islam berupa al-Qur'an dan al-Hadits.

3. Untuk mengembangkan konsepsi kurikulum Pendidikan Islam dalam rangka mencapai tujuan yang optimal perlu adanya pemahaman pada masing-masing konsepsi kurikulum yang sudah dirumuskan oleh para ahli pendidikan. Konsepsi kurikulum yang dimaksud adalah: kurikulum akademik, humanistik, teknologi, dan rekonstruksi sosial. Untuk konsepsi kurikulum pendidikan Islam dengan ciri-ciri: sistem pengajaran selaras dengan fitrah manusia, lebih 
Pengembangan Konsepsi Kurikulum Dalam Pendidikan Islam mengutamakan kepentingan umum daripada kepentinga pribadi, lebih mengutamakan amaliah (praktek) daripada nadhariah (teori). Dan dalam mengembangkan konsepsi kurikulum pendidikan Islam tersebut mengikuti prinsip proses pembelajaran; prinsip saling terkaitm menyeluruh / Kaffah, keseimbangan, kesesuaian, dinamis, keterbukaan, pemeliharaan, dan toleransi. 
Yunus Mustaqim

\section{DAFTAR PUSTAKA}

Ali, Muhammad. 1992. Pengembangan Kurikulum di Sekolah, Bandung: Sinar Baru.

an-Nahlawi, Abdurrahman. 1996. Ushûlu Tarbiyah al-Islâmiyah wa Asâlîbiha; fî al-Bait wa al-Madrasah wa al-Mujtam'a. Damsyiq: Darul Fikr.

. 1996. Ushûlu Tarbiyah al-Islâmiyah wa Asâlîbiha; fî al-Bait wa al-Madrasah wa al-Mujtam'a. Terjemahan oleh Shihabuddin. Pendidikan Islam di Rumah, Sekolah, dan Madrasah, Jakarta: Gema Insani Press

Engkoswara. 1984. Dasar-Dasar Metodologi Pengajaran, Jakarta: Bina Aksara.

Faesal, Jusuf Amir. 1995. Reorientasi Pendidikan Islam. Jakarta: Gema Insani Press.

Harsono, Eko Budi. 2004. Undang-undang tentang Pendidikan Agama Islam. Tersedia di http://www.suarapembaruan.com/ news $/ 2004 / 01 / 10 /$ kesra/ke02. htm. Diakses pada Tanggal 5 Juni 2015.

Ihsan, Hamdani dan A. Fuad Ihsan. 2007. Filsafat Pendidikan Islam. Bandung: CV Pustaka Setia.

McNeil, John. D. 1981. Curriculum: A Comprehensive Introduction, (Terj) Subandijah (1988), Kurikulum Sebuah Pengantar Komprehensif. Jakarta: Wira Sari.

Nasution. 1995. Asas-Asas Kurikulum. Jakarta: Bumi Aksara.

Sudjana, Nana. 1996. Pembinaan dan Pengembangan Kurikulum di Sekolah. Bandung: Sinar Baru Algensindo.

Tafsir, Ahmad. 1997. Metodologi Pengajaran Agama Islam. Bandung: Remaja Rosdakarya Offset. 